\title{
Relationship between geomorphology and contamination with weathered hydrocarbons in an old river levee/marsh association
}

\author{
${ }^{1 *}$ R. H. Adams, ${ }^{2}$ D. Olán-Castro, ${ }^{1}$ F. J. Guzmán-Osorio, ${ }^{1}$ I. J. Díaz-Ramírez \\ ${ }^{1}$ División Académica de Ciencias Biológicas, Universidad Juárez Autónoma de Tabasco. Carretera Villahermosa- \\ Cárdenas Km 0.5, Villahermosa, Tabasco, México. C.P. 86039 \\ ${ }^{2}$ Biosfera Tecnología Integral S.A. de C.V, Calle 1, Casa 1, Fracc. Amate, Carretera Villahermosa-Teapa Km $0+$ \\ 250 m, Villahermosa, Tabasco, México. C.P. 85126 \\ Received 1 June 2009; $\quad$ revised 23 July 2009; accepted 8 August 2009; $\quad$ available online 1 September 2009
}

\begin{abstract}
A site evaluation was made for a low-lying property in an old river levee/marsh association, used marginally for cattle raising, which was contaminated due to historical practices. Contamination was related to geomorphology: the lowest areas contained $79 \%$ of the contaminated samples. Other contaminated samples were all rear access roads (probable intentional dumping). There were no samples in the higher, levee areas away from roads with hydrocarbon concentrations above $3,000 \mathrm{mg} / \mathrm{kg}$. Medium and high impact levels, corresponding to average hydrocarbon concentrations of 13,400 mg/kg and 109,700 mg/kg, respectively, were found in $28 \%$ and $27 \%$ of the property area. The medium impact level was predicted to have a reduced pasture production potential of $\sim 50 \%$ while at the high impact level practically no pasture production was predicted. Toxicological risk to cattle is present in only $12 \%$ of the sample points although almost all of these are in very marshy areas not apt for cattle raising. Because the hydrocarbons at this tropical site are very weathered, acute toxicity was not related to hydrocarbon concentration. Although slightly more than half of the property has hydrocarbon concentrations above the permissible limit, only about one-third of the contaminated area is apt for cattle raising. This study, based on hydrocarbon distribution related to site geomorphology, soil toxicity bioassay, risk assessment to cattle and evaluation of pasture production allowed to made a more accurate assessment and definition of future use of the site. These criteria could be used for diagnostic studies of sites with similar tropical conditions.
\end{abstract}

Keywords: Crude oil; Livestock toxicity; Pasture production; Risk assessment

\section{INTRODUCTION}

In the southern Gulf of Mexico Region petroleum exploration, production, transportation and refining have taken place for at least 100 years (Petróleos Mexicanos, 1988). During the majority of this time, there was very little effort taken to preserve the nearby environment and industry wastes were dumped irresponsibly in nearby rivers, canals, marshes and swamps. Also, much of the infrastructure in the region is very old and pipelines especially are subject to chronic leaks and spills (Beltrán, 1993; Adams et al., 1999). During the last 20 years, this situation has slowly changed. Nowadays, there is a much greater concern in the industry to avoid contaminating the environment and to restore areas which have been deteriorated when this newer environmental consciousness was not present in society. Part of this

凶*Corresponding Author Email: drrandocan@hotmail.com Tel: +52 993330 1244; Fax: +52 9933544308 effort has been directed toward the evaluation of the damage caused in areas near petroleum installations, with the intention of paying restitution to property owners and over a longer term, the eventual remediation of impacted properties. In this sense, several soil characterization and diagnostic studies have been carried out in crude oil contaminated sites in this region. Cram et al., (2004) evaluated the mobility and content of PAH in sites with different spill histories and flooded conditions. They pointed out that the persistence of some PAH (polycyclic aromatic hydrocarbon) is due to limited microbial activity mostly where anaerobic conditions prevail and also to the low hydrocarbon availability to microorganisms (Okafor and Opuene, 2007; Opuene et al., 2007). A large number of oil spill sites have been identified near to the area of the present study. García-López et al. (2006) analyzed the relation 
between vegetal communities growing in different type of soils and the presence of hydrocarbons, finding that most of the spills were located in mangrove and others areas covered by native plants principally belong to Poaceae, Cyperaceae and Fabaceae plants families. In the area studied soil hydrocarbon content and distribution, as well as floristic description has been previously reported (Gallegos-Martínez et al., 2000). However, information about the geomorphology and their influence in the hydrocarbon distribution is limited. Recently, the interest for evaluate the relation between the geomorphology and the impact of human activities is an increasing field of study, especially in coastal zones or delta rivers systems with influence of fuels extraction activities as in the Niger delta area or Boao coastal system in south China (Benka-Coker and Ekundayo, 1995; Ekundayo and Obuekwe, 1997; Dakui et al., 2005). The alternative use of land, ecological restoration and cattle pasture production in old crude oil spills sites, as well as mining residues and pesticide affected areas are necessary and currently represent a social concern leading to litigation or agreements (Carvalho et al., 2002; Razo et al., 2006). It requires the inclusion of ecotoxicological assays, risk based criteria (Cram et al., 2004; Zavala-Cruz et al., 2005) and remote-sensing technology (Wang and Ding, 2000) during site characterization and diagnostic studies. Furthermore, the detailed analysis of soil geomorphology and flood patterns are relevant data for the development of remediation projects and for decision making by the authorities responsible (Iturbe et al., 2004; Osuji and Opiah, 2007). The main objective of the present study was to establish a relationship between the soil hydrocarbons distribution and site geomorphology during the characterization of a highly hydrocarbon impacted site. Here the geomorphology was considered as a useful tool for determining soil use and the probability of site contamination. In order to perform a more integral site assessment, factors other than just hydrocarbon concentration and composition were determined such as 1) ecotoxicological bioassays, 2) a combined metatype analysis of pertinent studies on pasture production vs. hydrocarbon concentration and 3 ) evaluation of hydrocarbon concentration with respect to toxicity on bovine cattle. This study was carried out in the Spring and Summer of 2008 at a site located in the southern Gulf of Mexico coastal plain, approximately $20 \mathrm{~km} \mathrm{SE}$ of the mouth of the Coatzacoalcos River, in Veracruz State, Mexico.

\section{MATERIAL AND METHODS}

Study area

The location has a Humid-Tropical, Monsoon climate, type Am in the Köppen classification system (Köppen, 1900). In the revised Thornthwaite (Thornthwaite-Feddema) classification system the climate is considered hot and wet with high climate variability due mainly to precipitation (Feddema, 2005). The average temperature is $25.6^{\circ} \mathrm{C}$ and the annual precipitation is 2,041 $\mathrm{mm}$ (Gobierno del Estado de Veracruz, 2005). The site consists of 80 ha in a very low-lying area $(<5 \mathrm{~m}$ above sea level), in the most southerly part of the Gulf of Mexico plain, at approximately $18^{\circ} 00^{\prime} \mathrm{N}, 9^{\circ} 30^{\prime} \mathrm{W}$. It consists of a series of bands of flooded, marshy areas and low, floodable but slightly higher areas with very gentle gradients, oriented in a North South direction with a deviation of $\sim 10^{\circ}$ towards the east. These are vestiges of natural river levees deposited parallel to the ancient course of the Coatzacoalcos River, in the southern part of Veracruz State, Mexico. The vegetation in the more marshy areas of the site consists of cattails (Typha latifolia), reeds (Phragmites australis) and briers (Mimosa spp.), among other species. Only in the highest parts of the study area, corresponding to very old and eroded natural levees and here only during the driest months of the year it is possible to use the soil for livestock raising (spring and late summer dry seasons). In these areas flood resistant pasture is maintained by the property owner. These higher areas occupy approximately half of the property, while the other, completely marshy areas occupy the other half. In the marshy areas there are parts which are extremely low-lying and in these there is a much greater tendency to encounter hydrocarbon contamination. This property is less than $2 \mathrm{~km}$ to the North-East of the oldest and largest petroleum refinery in Latin America. Evaluations of adjacent and nearby areas have shown the soil to be highly contaminated (Gallegos-Martínez et al., 2000). 


\section{Sample collection}

A grid was developed for sample collection with a sample point density according to Mexican Norm NOM-138-SEMARNAT/SS-2003 (SEMARNAT, 2005) of $0.75 /$ ha, consisting of 60 points for an 80 ha property. Samples were collected by hand auger in three strata: 1) $0-0.1 \mathrm{~m}, 2) 0.1-0.5 \mathrm{~m}, 3) 0.5-1.0 \mathrm{~m}$. Occasionally, samples in the first stratum were collected to depths of 20 or $30 \mathrm{~cm}$ when there was an obvious hydrocarbon contamination. Samples were placed in glass jars with Teflon seals and preserved at $4{ }^{\circ} \mathrm{C}$. In these very fine grained (muddy) samples, gravel and large particles were practically absent. A No. 20 mesh size sieve was used as necessary to remove occasional sticks and pebbles from the samples prior to analysis.

\section{Hydrocarbon analyses}

For hydrocarbon analysis, samples were sent to a laboratory accredited by the Mexican Accreditation Entity (in Spanish Entidad Mexicana de Acreditación, EMA), Laboratorios ABC Química, Investigación y Análisis, S.A. de C.V., in Mexico City. Samples were analyzed according to the methods indicated in Mexican Norm NOM-138-SEMARNAT/SS-2003, (SEMARNAT, 2005). Combined mid-range and heavyrange hydrocarbons were determined gravimetrically as the total extractable hydrocarbons by an EPA-1664A based method using hexane as the extraction solvent. Light fraction (C5 - C10) and mid-range fraction (C10 - C28) hydrocarbons were determined independently by EPA methods 8010 and 8015 , respectively. These methods use gas chromatography and the analyses run by EPA method 8015 were especially useful to determine not only the quantity of hydrocarbons, but also the type of hydrocarbon by comparison of the gas chromatograms. Light range hydrocarbons were determined using an Agilent 6890/G1530A gas chromatograph with a selective mass detector and purge-and-tramp apparatus (Agilent brand GC model $5973 \mathrm{M} / 62577 \mathrm{~A}, 0 . \mathrm{I}$ analytical brand purge-and-trap model 4560 and Agilent brand auto-sampler model 4552). The GC run parameters were as follows: initial temperature of $40^{\circ} \mathrm{C}$ for $1 \mathrm{~min}$ followed by a ramp of 5 ${ }^{\circ} \mathrm{C} / \mathrm{min}$ up to a final temperature of $210^{\circ} \mathrm{C}$ for five min. For these determinations a standard mix of hydrocarbons was obtained form Chem Service, Wisconsin using the PVC/GRO Mixture 1 USTW11RPM which was complemented with six pure substances to determine the correlation between carbon number and retention time. Areas obtained from the chromatograms were compared with runs of the $\mathrm{C}_{5}-\mathrm{C}_{10}$ standard to determine the quantity of light range hydrocarbons. The Chem Station/ Enviroquant Ver. D.01.02 was used to integrate the GC runs and quantify the hydrocarbons. Mid-range hydrocarbons were determined using hexane as the extraction solvent. Extracts were run on a Hewlett Packard model 5890 Series II gas chromatograph with a flame ionization detector (Horizon Technology, GC Racer model) and a Hewlett Packard model 5890 Series II auto-sampler model 4552. The GC run parameters were as follows: initial temperature of $60{ }^{\circ} \mathrm{C}$ for seven minutes followed by a ramp of $7^{\circ} \mathrm{C} / \mathrm{min}$. up to a final temperature of 310 ${ }^{\circ} \mathrm{C}$ for $5.73 \mathrm{~min}$. For these determinations, a standard mix of hydrocarbons was obtained form Chem Service, Wisconsin using the TPH5 RPM mixture at an equivalent concentration of $20,000 \mathrm{mg} / \mathrm{L}$ to determine the correlation between carbon number and retention time. Areas obtained from the chromatograms were compared with runs of the $\mathrm{C}_{10^{-}}$ $\mathrm{C}_{28}$ standard to determine the quantity of mid-range hydrocarbons. The Chem Station/Enviroquant Ver. A.10.02 software was used to integrate the GC runs and quantify the hydrocarbons. To calculate the concentration of heavy hydrocarbons, the results from analysis by method EPA 8015 were subtracted from the results for total extractable hydrocarbons (method EPA 1664A).

\section{Geomorphology}

The geomorphology was studied using satellite images from Google ${ }^{\mathrm{TM}}$ Earth which were relatively recent $(\sim 3 \mathrm{y})$. This was verified by field observation from access roads and by making five transects in the east-west direction. Additionally, hydrocarbon crusts were mapped in the field by following the contours of the crusts with respect to the marshy vegetation and levee areas.

\section{Toxicity bioassays}

To determine toxicity in the study area the bioassay using the bioluminescent bacteria Photobacterium phosphoreum was employed (NMX-AA-112-1995-SCFI, SECOFI, 1996). Since the publication of this method, the test organism has been reclassified as Vibrio fischerii. Briefly, tenfold dilution series were prepared from a suspect 
sample then the test organism was added according the supplier procedure $\left(\right.$ Microtox $\left.^{\mathrm{TM}}\right)$. A dose-response function was made from the data of reduction of bioluminescence respect sample concentration. Interpretation of the data was as follows: the sample concentration which produced a reduction of $50 \%$ in the bioluminescence was determined from the dose response function and reported as the effective concentration $50\left(\mathrm{EC}_{50}\right)$. According to this interpretation a lower value of $\mathrm{EC}_{50}$ corresponds to a higher toxicity value. Later, based on the $\mathrm{EC}_{50}$ value, a toxicity unit (TU) value was calculated as $\mathrm{TU}=1 / \mathrm{EC}_{50}$, with $\mathrm{EC}_{50}$ as a fraction, thus a higher TU value corresponds to a higher toxicity.

\section{Pasture production analysis}

In order to calculate reduction in pasture production in the study area, data from two very similar previous studies from a nearby area (Rivera and Trujillo, 2004; Zavala et al., 2005) were normalized and combined to obtain a data set with a larger number of samples for better interpretation (meta- type analysis). In these previous studies, soil was collected from the same oil field in marshy conditions, soil samples with different concentrations of weathered hydrocarbons were planted with Egyptian pasture (Brachiaria mutica) and aerial biomass production was evaluated with respect to TPH (total petroleum hydrocarbons) concentration. The data from these studies was normalized with respect to the biomass production; the biomass production was calculated as a percentage of that for soil samples with null or very low TPH concentrations. Using the combined data a typical dose-response function was performed.

\section{RESULTS AND DISCUSSION}

\section{Geomorphology}

From a greater perspective, using satellite imagery, contaminated areas can be observed near the refinery installations, which have been contaminated due to historic practices, above all just to the north and especially to the east of the refinery. In this area, large extensions of up to $\sim 1$ ha can be encountered which have a practically continuous crust of hydrocarbons. This same anthropic geoform extends towards the North and North-East, into the most southwesterly part of the property in question, especially in the lower, marshy areas between the slightly higher river levees (Fig. 1). In the low-lying area between river levees starting in the most southern part of the property and extending toward the N-NE for $\sim 1 / 2 \mathrm{~km}$, a mosaic of hydrocarbon crust and hydrocarbon impregnated organic material (peat) covered with marsh vegetation is observed (Fig. 1). As this geoform advances towards the North-North East (and away from the refinery), the degree of hydrocarbon contamination tends to be reduced.

\section{Chemical analysis}

In order to evaluate the hydrocarbons concentration distribution in the contaminated area a sample point grid was designed (Fig. 2). Samples from

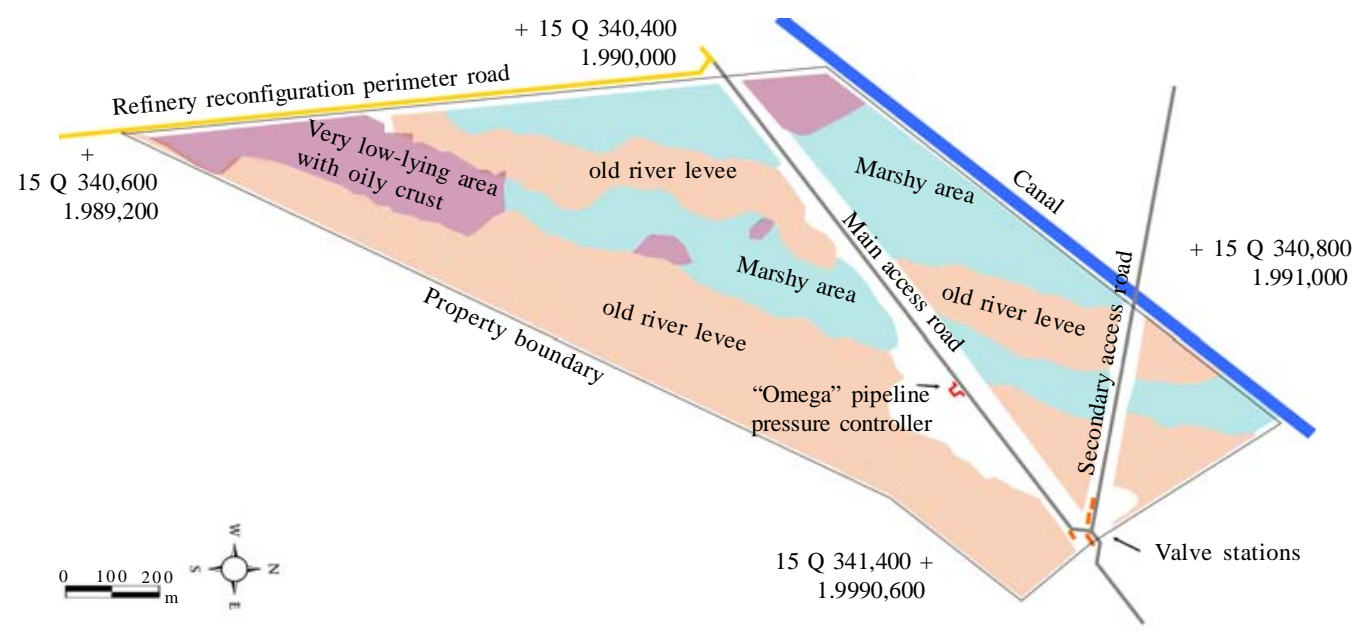

Fig. 1: Geomorphology of the study area. Cross-hatch coordinates are in the Universal Transverse Mercator system 
60 points were collected and analyzed for hydrocarbon concentrations. In almost all of the sampling points $(\sim 85 \%)$ the maximum hydrocarbon concentrations were observed in the superficial sampling layer (stratum $0-0.1 \mathrm{~m}$ deep), and in many sampling points hydrocarbons were found only in this stratum. This is congruent with the behavior of hydrocarbons in this type of marshy environment. The hydrocarbons are less dense than water, and tend to float and not penetrate the lower strata. Also, the hydrocarbons are mainly absorbed in the organic matter which has a polarity more similar to the hydrocarbons than to water or soil minerals; organic material is highly accumulated in the surface due to primary production of vegetable material (Cram et al., 2004). Of the samples analyzed, in 23 of the 60 sampling points, hydrocarbons were not found, or only in very low concentrations (range: $0-1,600 \mathrm{mg} / \mathrm{Kg}$, dry weight; average $700 \mathrm{mg} / \mathrm{Kg}$ ). In almost all of these sampling points hydrocarbons were only detected in the surface stratum. $87 \%$ of the hydrocarbons were of the heavy fraction (>C28), and in some cases, where the concentration is very low, this may even be confused with naturally occurring marsh organic material.

The marshy soil at this site has a high organic matter content, making it difficult to discriminate from petroleum hydrocarbons of high molecular weight.
Besides these 23 sampling points with very low hydrocarbon concentrations in the superficial stratum, four sampling points were found in which the hydrocarbon concentration in stratum 1 is higher, but still below $3,000 \mathrm{mg} / \mathrm{Kg}$, the maximum permissible limit for heavy fraction hydrocarbons according to Mexican norm for non industrial sites (SEMARNAT, 2005). The combination of these 27 points has a superficial stratum with an average hydrocarbon concentration of $860 \mathrm{mg} / \mathrm{Kg}$ (Table 1), and represents almost half of the sampling points. The hydrocarbons found in this set are $~ 88 \%$ heavy range ( $>\mathrm{C} 28$ ), $12 \%$ are mid-range $(\mathrm{C} 11-\mathrm{C} 28)$, and no light range hydrocarbons were found (C5 - C10). Twenty four of these 27 points $(88 \%)$ with low or very low concentrations were found in the higher parts of the property (old river levee). In the other sampling points, areas of medium and high impact were observed; results are presented in Table 1. In 17 of these points (28\%), a medium degree of impact was observed. The average concentration of total petroleum hydrocarbons in the superficial stratum in these samples was $13,400 \mathrm{mg} / \mathrm{kg}$, of which $73 \%$ is heavy range and $27 \%$ is mid-range and a trace of low range hydrocarbons was also found (Table 1). Gas chromatograms show a unresolved complex mixture, characteristic of highly weathered hydrocarbons,

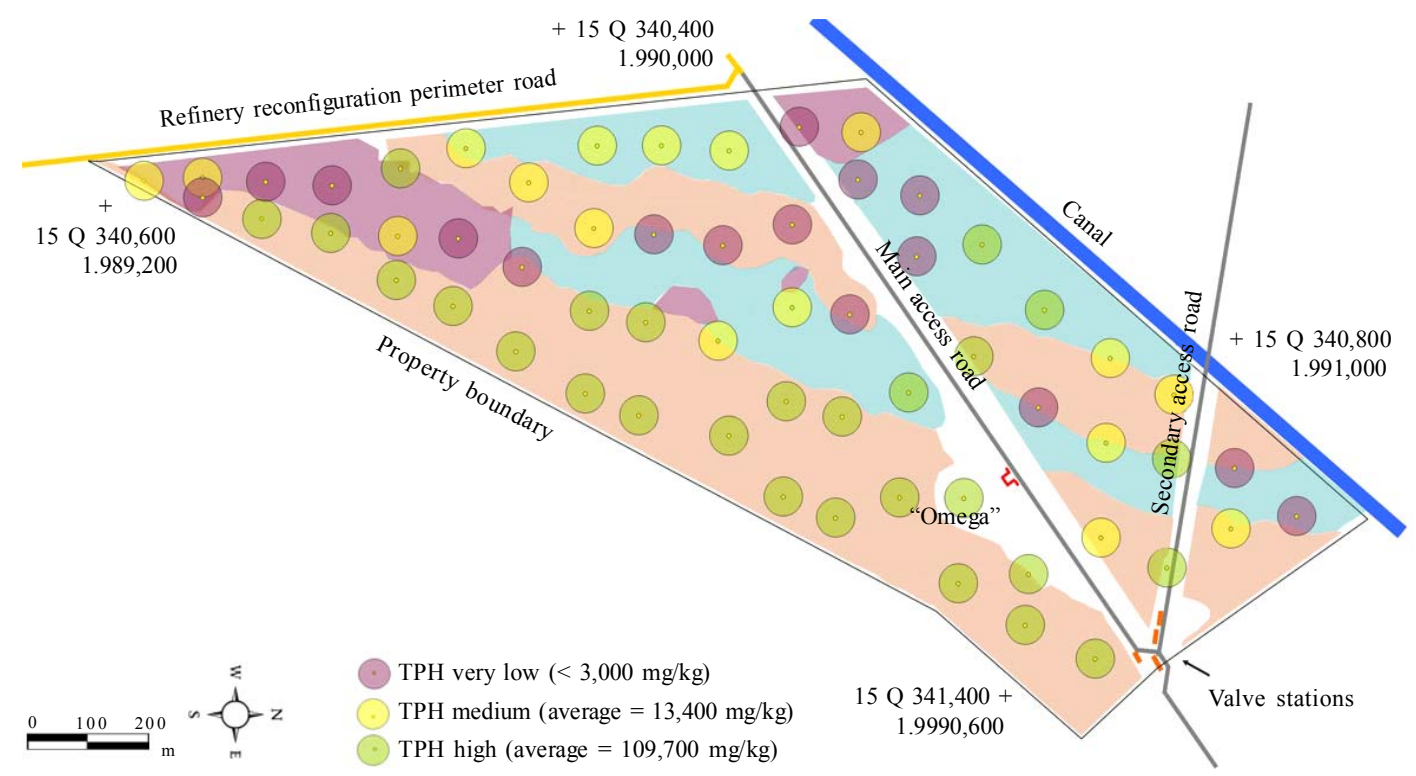

Fig. 2: Distribution of soil sampling points. Hydrocarbons concentrations are indicated 
R. H. Adams et al.

Table 1: Characteristics of hydrocarbon impacted parts of the study area

\begin{tabular}{|c|c|c|c|c|c|}
\hline Level of impact & TPH (mg/kg*) & $\begin{array}{c}\mathrm{HRH}^{\mathrm{a}} \\
(\%)\end{array}$ & $\begin{array}{c}\mathrm{MRH}^{\mathrm{b}} \\
(\%)\end{array}$ & $\begin{array}{c}\mathrm{LRH}^{\mathrm{c}} \\
(\%)\end{array}$ & Observations \\
\hline $\begin{array}{l}\text { Low (average) } \\
\text { (interval) }\end{array}$ & $\begin{array}{l}860 \\
(\mathrm{ND}-2,200)\end{array}$ & 88 & 12 & $\begin{array}{l}\text { Not detected } \\
\text { (ND) }\end{array}$ & $\begin{array}{l}45 \% \text { of sampling points. Grand majority are in levee } \\
\text { areas. Almost all samples only have heavy } \\
\text { hydrocarbons. There is a tendency to have a much } \\
\text { higher concentration in the surface stratum. }\end{array}$ \\
\hline $\begin{array}{l}\text { Medium } \\
\text { (interval) }\end{array}$ & $\begin{array}{l}13,400 \\
(4,600-24,500)\end{array}$ & 73 & 27 & trace & $\begin{array}{l}28 \% \text { of sampling points. } 3 / 4 \text { are in low-lying areas. } \\
\text { Very weathered hydrocarbons. }\end{array}$ \\
\hline $\begin{array}{l}\text { High } \\
\text { (interval) }\end{array}$ & $\begin{array}{c}109,700 \\
(51,000-184,000)\end{array}$ & 65 & 35 & trace & $\begin{array}{l}27 \% \text { of sampling points. } 4 / 5 \text { are in low-lying areas. } \\
\text { Very weathered hydrocarbons; however there is a } \\
\text { higher proportion of } \mathrm{C} 15-20 \text { range hydrocarbons than } \\
\text { in the samples with a medium level of impact. } \\
\text { Probably due to more recent contamination. }\end{array}$ \\
\hline
\end{tabular}

* Hydrocarbon concentrations (ppm) are in units of $\mathrm{mg} / \mathrm{kg}$, on a dry weight basis. ${ }^{\mathrm{a}} \mathrm{HRH}$ : Heavy range hydrocarbons ${ }^{\mathrm{b}} \mathrm{MRH}$ : Medium range hydrocarbons c LRH: Light Range Hydrocarbons

composed principally of cyclic and branched alkanes, polycyclic aromatic hydrocarbons, as well as other polar resin-types compounds (Díaz-Ramírez et al., 2003). This is in agreement with the results from a characterization that was done on hydrocarbons near the refinery several years ago in which $32.4 \%$ of the hydrocarbons were asphaltenes, $39.8 \%$ aliphatics, $\quad 18.9 \%$ aromatics and $9.1 \%$ polar compounds (Gallegos-Martínez et al., 2000; SEMARNAT, 2004). Thirteen of the 17 sampling points $(76 \%)$ were in or on the edge of the low, marshy, inter-levee areas in the property (Fig. 3). Of the four points not in the marshy area, two of these are in the western most levee of the property. This levee is somewhat lower and closer to access roads. These two points lie in an area for which restitution was paid previously for to damages resulting from the intentional dumping of semi-solid oily waste by industry personnel. The other two points are near an access road in the northern part of the property. Due to this location and previous site history, it is probable that these areas were also contaminated due to intentional dumping near the road. In only 16 of the sampling points $(27 \%)$ did we find a high level of contamination in stratum 1 . In these samples, the average TPH concentration was $109,700 \mathrm{mg} / \mathrm{kg}$, of which $65 \%$ corresponded to heavy hydrocarbons, $35 \%$ corresponded to midrange hydrocarbons and there was also a trace of light hydrocarbons (>C28, C11-C28, and C5 $\mathrm{C} 10$, respectively). The chromatograms from these samples are very similar to those previously described for samples with a medium degree of impact; however they appear to be less weathered, presenting a greater percentage of hydrocarbons in the $\mathrm{C} 15$ - $\mathrm{C} 20$ range. It is probable that the contamination source in these areas is more recent. Of these 16 sampling points, $13(81 \%)$ are in, or on the edge of the low, marshy areas of the property (Fig. 3). The exceptions are all in the western most levee and the area for which restitution was paid previously due to intentional dumping.

\section{Impacted areas}

Using all of the available information, combining the findings of geomorphology and the chemical analyses, areas with medium and high degrees of impact were delineated (Fig. 3). The majority of the impacted area is in the low-lying, marshy parts of the property with the exceptions of the western levee in the extreme Northern most part of the site (near a secondary access road) and also, just south of this area. A description in greater detail of these areas follows:

\section{Low-lying areas}

These include almost all of the inter-levee areas that transect the property from South-South west to $\mathrm{N}-\mathrm{NE}$ with the exception of an area approx. $300 \mathrm{~m}$ long in the center of the property (and mostly away from roads) and a small area approx. $50 \mathrm{~m}$ long south of the secondary access road that crosses the canal in the northern part of the property (Fig. 3). This also includes the majority of the low-lying area to the north of the main access road except for a stretch approx. $250 \mathrm{~m}$ long in the middle of this area. It is 


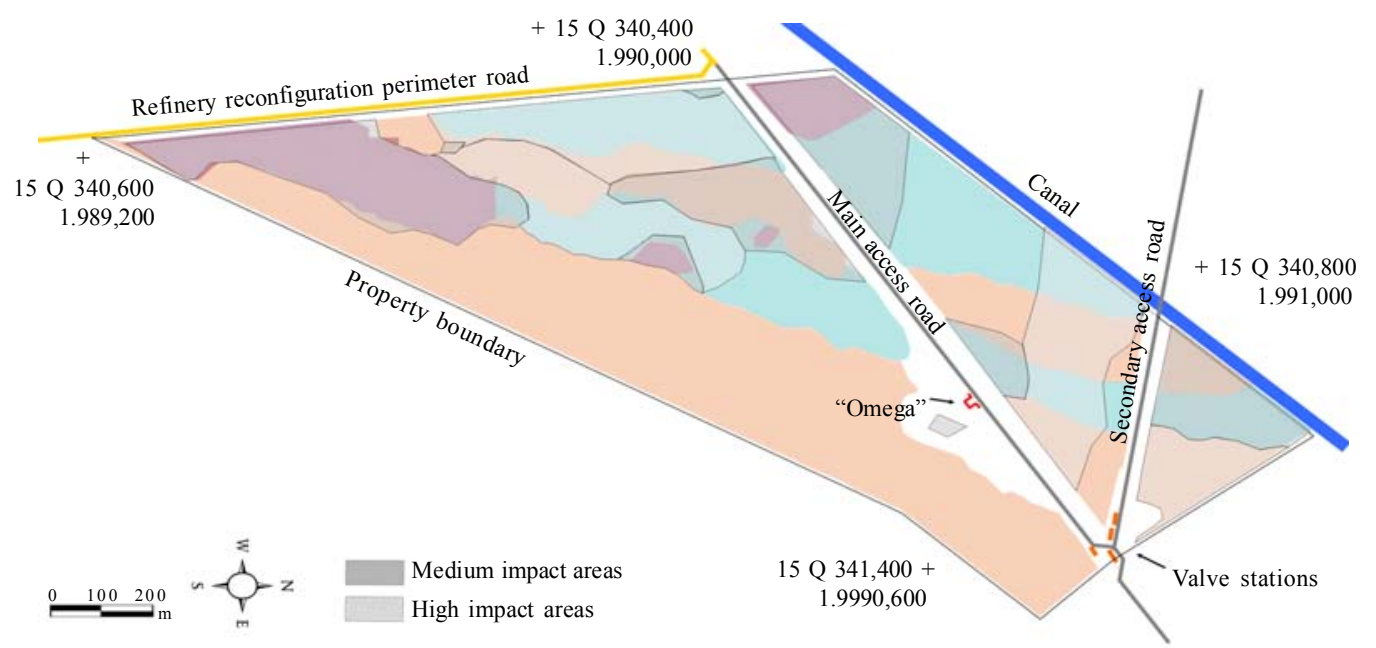

Fig. 3: Areas with medium and high levels of impact

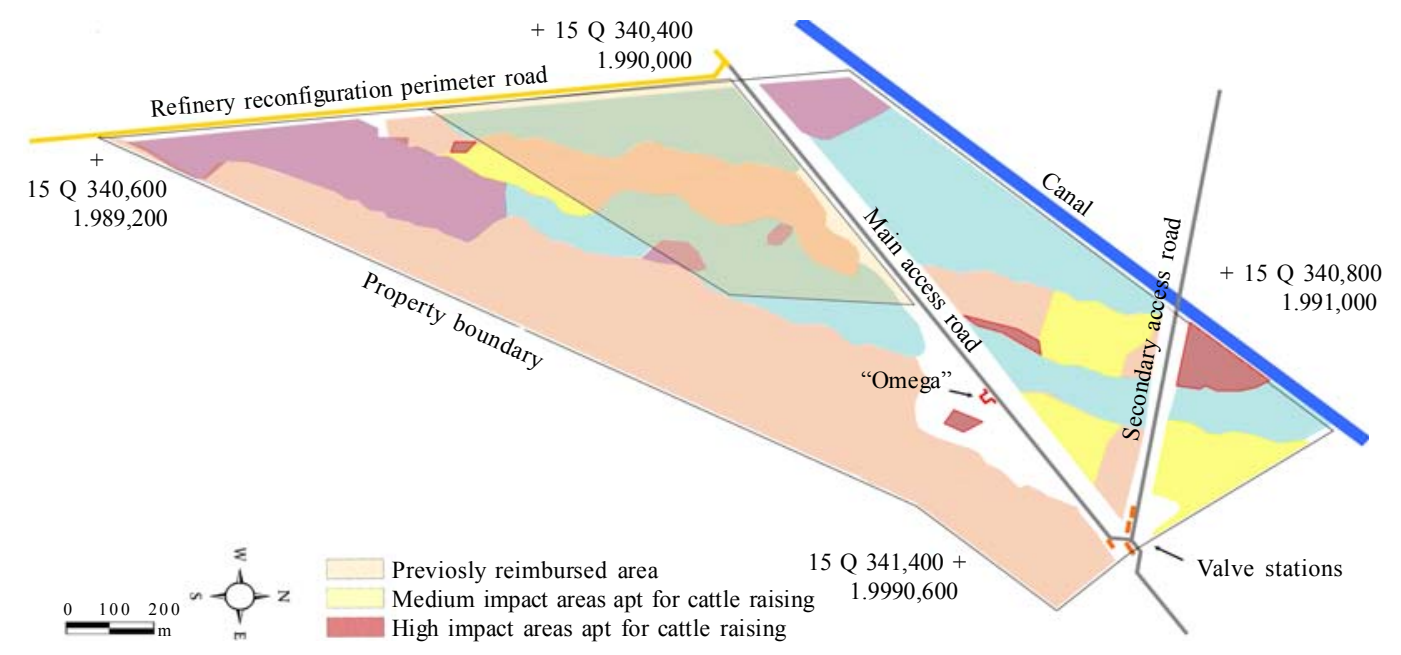

Fig. 4: Cattle raising areas with medium and high levels of impact

important to mention that none of these areas are able to be used for cattle raising due to their marshy nature, independent of the degree of hydrocarbon contamination.

\section{Old levee areas}

These include the entire levee areas located at the north of the secondary access road that crosses the canal and about one-half of the levee area south of this access road and NE of the main access road (Fig. 3). Also, it includes a small area near an "omega" (U or $\Omega$ shaped pipeline pressure controller) which is $\mathrm{SE}$ and alongside the main access road. The extension of all these areas is 5.5 ha. The fourth area of levee impacted includes the major part of the western levee (which is somewhat lower and closer to access roads) and has an extension of approx. 5.3 ha. In this last area, approx. 4.4 ha are located in a part of the property for which restitution was paid previously due to intentional dumping and approx. 0.9 ha are outside of this area. In Fig. 4 areas with different levels of impact are shown. Of the contaminated levee geomorphology, 
there are areas of high impact (average TPH concentration of $109,700 \mathrm{mg} / \mathrm{kg}$ ) and areas of medium impact (average TPH concentration of 13,400 mg/ $\mathrm{kg}$ ). The extension of levee with a high impact and not previously reimbursed is approx. $1.0 \mathrm{ha}$, whereas the extension of the levee areas with a medium impact and not previously reimbursed is approx. 5.4 ha. According to the results of geomorphology analysis, soil hydrocarbon content and field observations, these areas can be used for cattle raising, but only marginally, during the months of drought.

\section{Degree of impact}

In order to determine the degree of impact in the contaminated areas, with possible cattle raising use, a combined quantitative evaluation was made. This approach includes the analysis of site-soil toxicity measurements, bovine cattle hydrocarbon exposure risk data and impact on pasture production in very similar hydrocarbon polluted soils.

\section{Toxicity bioassays}

Representative samples from areas of null or very low hydrocarbon concentrations, as well as samples for medium and high hydrocarbon concentrations were selected according to the chemical analyses specified in Mexican Norm NOM-138-SEMARNAT/ SS-2003. These data are reported in Toxicity Units $\left(1 / \mathrm{EC}_{50}\right.$, on a fraction basis). Several samples of areas without, or practically without hydrocarbons, did not present toxicity and these were assigned a value of $10 \mathrm{TU}$, based on regional studies of similar noncontaminated soils (Adams, 2004). The results of this evaluation are presented in Fig. 5. As shown in Fig. 5, the toxicity was very variable and did not correspond to the concentration of hydrocarbons in the soil; the hydrocarbons in the soil did not increase the toxicity. Using a comparison of means, no significant difference was observed between the different sets of samples (confidence interval of 95 $\%$ ). This is in agreement with the evaluation of chromatograms which indicate very weathered hydrocarbons, which are of low or almost null toxicity (Gustafson et al., 1997). It could also be due to high sorption into organic matter and soil clay fraction of the high molecular weight residual compounds and hydrophobic complex mixtures, greatly reducing the availability (Luthy et al., 1997).

\section{Hydrocarbon toxicity to bovine cattle}

Bovine cattle can be exposed to contaminants principally by direct consumption of soil (Zach and Mayoh, 1984). Normally, cattle consume around six percent of their daily ingestion as soil; as particles of soil attached to the grass which they consume, or directly to obtain salts and other mineral deficient in their diet (IAEA, 1994). Adams and Morales-Garcia (2008a) evaluated this exposure route for very weathered hydrocarbons basing their evaluation on a previous dose-response study that was carried out on calves given crude petroleum in their diet (Stober, 1962; Pattanayek and DeShields, 2003), as well as data on the ingestion rate of pasture by bovine cattle in Tabasco state (Southern Mexico, Tobias, 1997). According to their calculation, if the concentration of weathered hydrocarbons in the soil is less than $127,879 \mathrm{mg} / \mathrm{kg} \mathrm{TPH}$, there is no appreciable risk to the cattle. Seven of the 60 sampling points presented TPH concentrations higher than this. Of these, five sampling points correspond to the very low-lying areas where cattle raising is not possible (Fig. 5) and two sampling points correspond to levee areas, but in the part of the property previously reimbursed due to intentional dumping.

\section{Impact on pasture production}

According to the chromatograms, the hydrocarbons in the samples are highly weathered, principally $\mathrm{C} 13+$. These kinds of hydrocarbons have very low toxicity, but they do alter physical-chemical properties which are important for soil fertility such as field capacity, cation exchange capacity, bulk density, porosity, $\mathrm{pH}$, electrical conductivity and soil temperature (Adams et al., 2008b, 2008c). Several studies have been made related to pasture production in marshy soils impacted by weathered hydrocarbons in the region. Zavala et al. (2005) selected soil from spill areas in the western region Tabasco State (about $40 \mathrm{~km}$ from the current study area), with different hydrocarbon concentrations. In these soils, they evaluated the development of Egyptian pasture (Brachiaria mutica). In that study they found a marked decrease in pasture production in soil with more than $6,000 \mathrm{mg} / \mathrm{kg}$, observing a reduction of about $65 \%$ in soil with a TPH concentration of $21,000 \mathrm{mg} / \mathrm{kg}$. In a study by Rivera and Trujillo (2004), clayey-organic rich soil contaminated with weathered 
hydrocarbons was collected from the same area studied by Zavala et al. (2005). Aerial biomass of Egyptian pasture was measured respect to TPH concentration. At concentrations above $10,000 \mathrm{mg} /$ $\mathrm{kg}$ a marked reduction in pasture production was observed and at a concentration of about $80,000 \mathrm{mg} /$ $\mathrm{kg}$ pasture production was only about $7 \%$ of that in a practically non-contaminated soil from the same site.

The soil for both of these studies was collected in the same oil field, in marshy soils and both used
Egyptian pasture to study aerial biomass production in relation to TPH concentration. Considering these similarities, it was considered reasonable to combine the data for a more complete analysis. The data were normalized and combined to obtain a set with a larger number of samples for better interpretation (similar to meta-analysis).

The results of this interpretation are shown in Fig. 6. A typical dose-response curve was calculated for the combined data obtaining a very good correlation $(r=0.94)$. From this function, a biomass

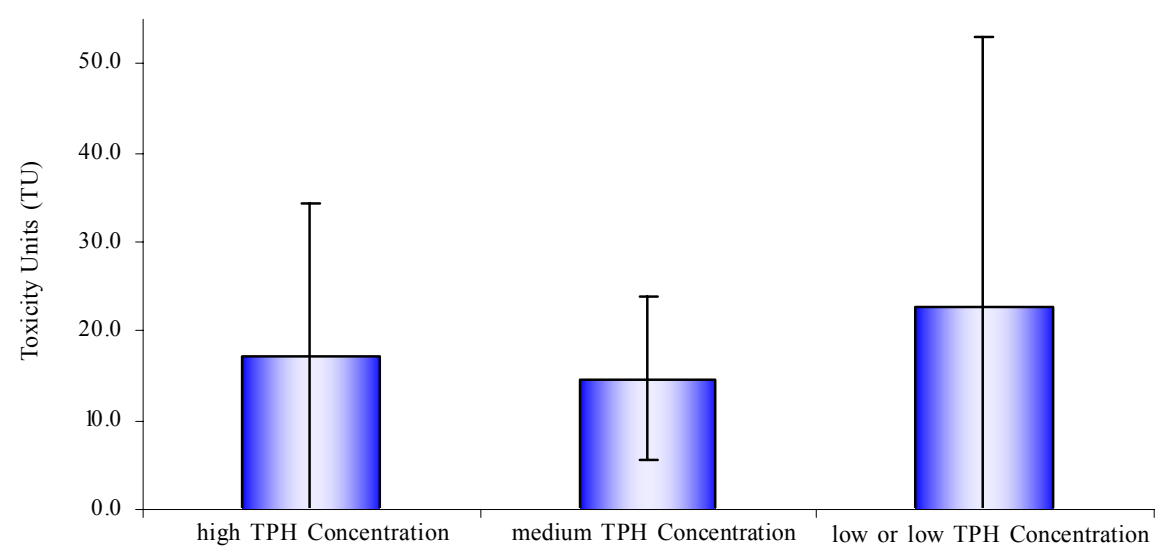

Fig. 5: Toxicity in soil samples from the study area. Column height represents average values from at least 15 samples, the length of the overlying bars represent one standard deviation

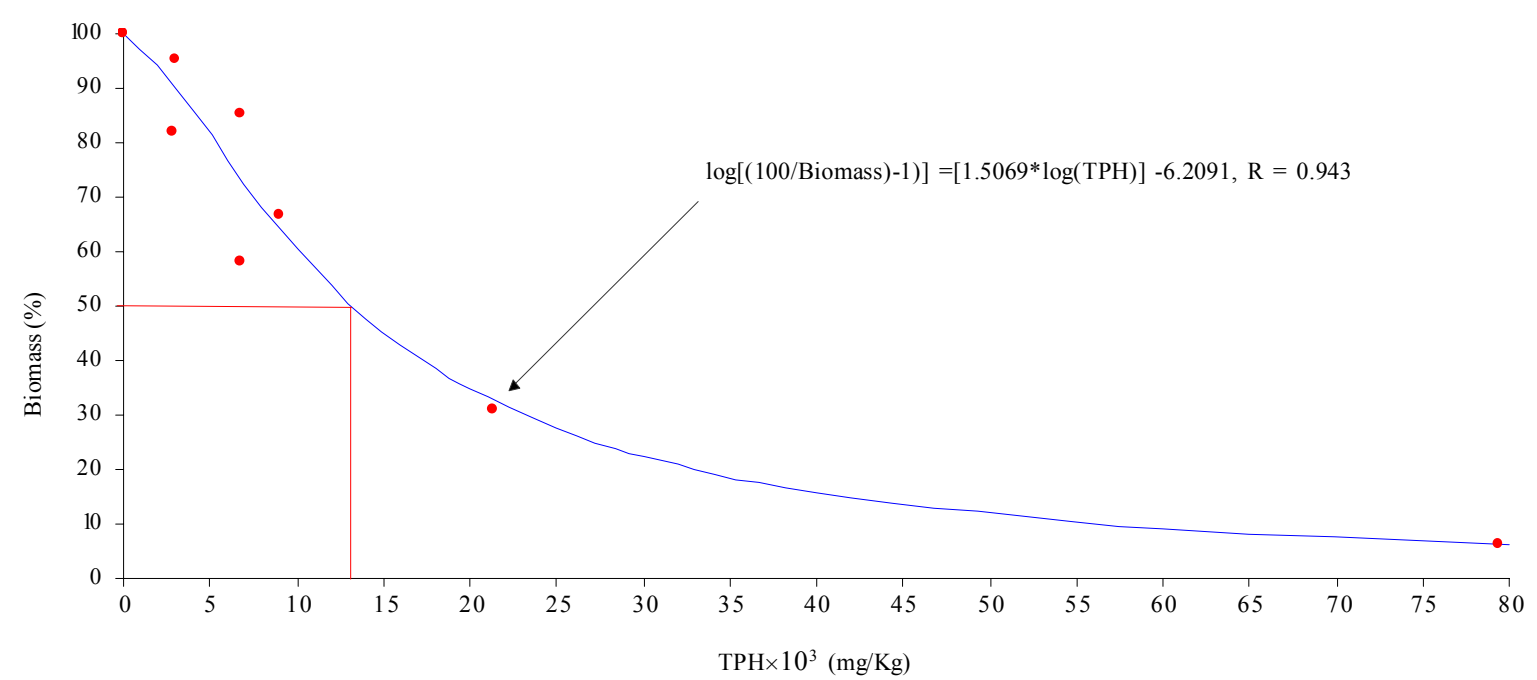

Fig. 6: Dose-response relationship for Egyptian pasture growing in hydrocarbon contaminated soil - normalized and combined data (meta- type analysis) 
reduction of $50.6 \%$ was calculated for the soil with a medium impact level of $13,400 \mathrm{mg} / \mathrm{kg}$ TPH (average) in the study area near the refinery. Likewise, for the parts of the property with a high level of impact (average of $109,700 \mathrm{mg} / \mathrm{kg} \mathrm{TPH}$ ), nearly complete reduction $(>96 \%)$ of pasture production was calculated.

\section{CONCLUSION}

In this low-lying old river levee/marsh association hydrocarbon concentration was determined basically by three factors: 1) geomorphology, the lowest areas were more likely to be more contaminated, 2) nearness to access roads (intentional dumping) and 3) nearness to the historical contaminant source (refinery). None-theless, even at very high hydrocarbon concentrations $(\sim 11 \%)$ soil toxicity was not measurably affected. Hydrocarbon concentrations restrictive of cattle use due to toxicological risk were encountered in about $12 \%$ of the samples. Of these, about eight percent correspond to migration of oily wastes into low-lying areas (not apt for cattle raising due to marshy conditions) and about four percent correspond to higher levee areas, near to access roads, where hydrocarbons were intentionally dumped several decades ago. Pasture production potential as calculated by a combined analysis of data from similar areas indicated that the areas with a medium level of impact (average of $13,400 \mathrm{mg} / \mathrm{kg} \mathrm{TPH}$ ) could support a pasture production of about $50 \%$ with respect to background levels, while in those areas with a high level of impact (average TPH concentration of $109,700 \mathrm{mg} / \mathrm{kg}$ ) pasture production would be practically null.

In this study, care was taken when evaluating damages to the property owner to differentiate between those parts of the property where use for cattle raising is feasible and where it is not possible due to marshy conditions. Independent of hydrocarbon contamination, only about half of the property is apt for cattle raising. Of this area, about 8 ha $(18 \%)$ had been included in a 14.6 ha area for which restitution was paid previously due to intentional dumping. Of the remaining acreage apt for cattle raising (about $33 \mathrm{ha}$ ), 5.4 ha (about $16 \%$ ) had a medium degree of impact and 1.0 ha (about 3 $\%$ ) had a high degree of impact.
The importance of geomorphology, a toxicity bioassay, risk assessment to cattle and evaluation of pasture production were key to a correct interpretation of the data and assessment of the site. These factors will probably be important for site evaluation in other tropical and semitropical areas with petroleum production, transport or refining in river deltas such as: Southern Louisiana (USA), the Niger River Delta, the Llanos region and Orinoco River Delta (Venezuela) and possibly some parts of South East Asia such as Malaysia, Brunei and Indonesia and in Southern China, especially Guangdong Province.

\section{ACKNOWLEDGEMENTS}

Authors wish to thank to the Biosfera Tecnología Integral group for their mindful soil sampling and logistics. Also to the UJAT - Bioremediation Laboratory team for their assistance in the toxicity analysis and image handling. Likewise, thanks go to the laboratory personnel at the hydrocarbon testing laboratory, Laboratorios ABC Química, Investigación y Análisis, S.A. de C.V., for determination of hydrocarbon type and concentration.

\section{REFERENCES}

Adams Schroeder, R. H.; Domínguez Rodríguez, V. I.; García Hernández, L., (1999). Potencial de la biorremediación de suelo y agua impactado por petróleo en el trópico Mexicano. Terra., 17 (2), 159-174 (16 pages).

Adams, R. H., (2004). Chemical -biological stabilization method for treatment of drilling cuttings and hydrocarbon contaminated soil. $11^{\text {th. International Environmental }}$ Petroleum Conference. International Environmental Petroleum Consortium. Albuquerque NM, USA. (http:// ipec.utulsa.edu/Conf2004/ Papers/adams.pdf)

Adams, R. H.; Morales-García, F., (2008a). Concentración residual de hidrocarburos en suelo del trópico: Parte I. Consideraciones para la salud publica y protección al ganado. Interciencia, 33 (7), 476-482 (7 pages).

Adams, R. H.; Zavala Cruz, J.; Morales-García, F., (2008b). Concentración residual de hidrocarburos en suelo del trópico: Parte II. - Afectación a la fertilidad y su recuperación. Interciencia., 33 (7), 483-489 (7 pages).

Adams, R. H.; Guzmán-Osorio, F. J.; Zavala-Cruz, J., (2008c). Water repellency in oil contaminated sandy and clayey soils. Int. J. Environ. Sci. Tech., 5 (4), $445-454$ (10 pages).

Beltrán, J. E., (1993). Los impactos del petróleo. In: Tabasco: Realidad y perspectivas. Gobierno del Estado de Tabasco. Villahermosa, Mexico, D.F.

Benka-Coker; M. O.; Ekundayo, J. A., (1995). Effects of an oil spill on soil physico-chemical properties of a spill 
site in the Niger delta area of Nigeria. Environ. Monit. Assess., 36 (2): 93-104 (12 pages).

Carvalho, F. P.; Villeneuve, J. P.; Cattini, C.; Tolosa, I.; Montenegro-Guillén, S.; Lacayo, M; Cruz, A., (2002). Ecological risk assessment of pesticide residues in coastal lagoons of Nicaragua. J. Environ. Monit., 4 (5), 778-787 (10 pages).

Cram, S.; Siebe, C.; Ortíz-Salinas, R.; Herre, A., (2004). Mobility and Persistence of petroleum hydrocarbons in peat soils of southeastern Mexico. Soil Sed. Contaminat. 13 (5), 341-360 (20 pages).

Dakui, Z.; Yong, Y.; Martini, L. P., (2005). Geomorphology of the Boao coastal system and potential effects of human activities - Hainan Island, South China. J. Geogr. Sci., 15 (2), 187-198 (12 pages).

Díaz-Ramírez, I. J.; Gutiérrez-Rojas, M.; Ramírez-Saad, H.; Favela-Torres, E., (2003). Biodegradation of Maya crude oil fractions by bacterial strains and a defined mixed culture isolated from Cyperus laxus rhizosphere soil in a contaminated site. Can. J. Microbiol., 49 (12), 755-761 (7 pages).

Ekundayo, E. O.; Obuekwe, C. O., (1997). Effects of an oil spill on soil physico-chemical properties of a spill site in a typic paleudult of midwestern Nigeria. Environ. Monit. Assess., 45 (2), 209-221 (13 pages).

Feddema, J. J., (2005). A revised Thornthwaite-type global climate classification. Phys. Geogr., 26 (6), 442-466 (25 pages).

Gallegos-Martínez, M.; Gómez-Santos, A.; González-Cruz, L.; Montes de Oca-García, M. A.; Yáñez-Trujillo, L.; Zermeño-Eguía Lis, J.A.; Gutiérrez-Rojas, M., (2000). Diagnostic and resulting approaches to restore petroleumcontaminated soil in a Mexican tropical swamp. Water Sci. Tech., 42 (5-6), 377-384 (8 pages).

García-López, E.; Zavala-Cruz, J.; Palma-López, D. J., (2006). Caracterización de las comunidades vegetales en un área afectada por derrames de hidrocarburos. Terra Latinoamericana, 24 (1), 17-26 (10 pages).

Gobierno del Estado de Veracruz, (2005). Enciclopedia de los municipios de México, Estado de Veracruz de Ignacio de la Llave. Instituto Nacional para el Federalismo y el Desarrollo Municipal. Xalapa, Veracruz, México. http:// www.e.local.gob.mx/work/templates/enciclo/ veracruz/

Gustafson, J.; Griffith Tell, J.; Orem, D., (1997). Selection of representative $\mathrm{TPH}$ fractions based on fate and transport considerations. Total Petroleum Hydrocarbon Criteria Working Group Series, Vol. 3. The Association of Environmental Health and Sciences, Massachussettes, USA.

IAEA, (1994). Handbook of parameter values for the prediction of radionucleotide transfer in temperate environments. International Atomic Energy Agency. Technical Report Series No. 364. Vienna, Austria.

Iturbe, R.; Flores, R. M.; Flores, C. R.; Torres, L. G., (2004). TPH-contaminated Mexican refinery soil: health risk assessment and the first year of changes. Environ. Monit. Assess., 91 (1-3), 237-255 (19 pages).

Köppen, W., (1900). Versuch einer Klassifikation der Klimate, Vorzugsweise nach ihren Beziehungen zur
Pflanzenwelt. Geog. Z., 6 (593-611), 657-679 (23 pages).

Luthy, R. G.; Aiken, G. R.; Brusseau, M. L.; Cunningham, S. D.; Gschwend, P. M.; Pignatello, J. J.; Reinhard. M.; Traina, S. J.; Weber, W. J.; Westall, J. C., (1997). Sequestration of hydrophobic organic contaminants by geosorbents. Environ. Sci. Tech., 31 (12), 3341-3347 ( 7 pages).

Okafor, E. Ch., Opuene, K., (2007). Preliminary assessment of trace metals and polycyclic aromatic hydrocarbons in the sediments. Int. J. Environ. Sci. Tech., 4 (2), 233-240 (8 pages)

Opuene, K.; Agbozu, I. E.; Ekeh, L. E., (2007). Identification of perylene in sediments: Occurrence and diagenetic evolution. Int. J. Environ. Sci. Tech., 4 (4), 457-462 (6 pages).

Osuji, L. C.; Opiah, U. C., (2007). Hydrocarbon contamination of a terrestrial ecosystem: The case of Oshire-2 oil spill in Niger Delta, Nigeria. Environmentalist., 27 (3), 337-340 (4 pages).

Pattanayek, M.; DeShields, B., (2003). Characterizing risks to livestock from petroleum hydrocarbons. $10^{\text {th. }}$ Annual International Environmental Petroleum Conference, University of Tulsa/ Integrated Petroleum Environmental Consortium. http://ipec.utulsa.edu/Ipec/Conf 2003/ Papers/pattanayek_deshields_29.pdf

Petróleos Mexicanos., (1988). El Petróleo. Gerencia de Información y Relaciones Públicas, México, D.F.

Razo, I.; Diaz-Barriga, F.; Castro, J.; Marcos M., (2006). Environmental geochemistry studies and health risk assessment to identify priority areas for remediation of polluted soils in the Santa Maria de la Paz (S.L.P., Mexico) mining district. Chinese J. Geochem., 25 (Suppl.), 61

Rivera-Cruz, M. C.; Tujillo-Narcía, A., (2004). Estudio de toxicidad vegetal en suelos con petróleos nuevo e intemperizado. Interciencia, 29 (7), 369-376 (8 pages).

SECOFI (1996). Norma Mexicana NMX-AA-112-1995SCFI, Análisis de agua y sedimento - Evaluación de toxicidad aguda con Photobacterium phosphoreum. Secretaría de Comercio y Fomento Industrial. Método de prueba. Secretaria de Comercio y Fomento Industrial (SECOFI), Dirección General de Normas, México, D.F.

SEMARNAT (2004). Oficio No. DGGIMAR. 710/003255. Autorización para el tratamiento de residuos peligrosos. Secretaria de Medio Ambiente y Recursos Naturales. Autorización No. 30-108-GM-V-04-2004. No. de registro ambiental PREM00901611.

SEMARNAT (2005). Norma Oficial Mexicana NOM-138SEMARNAT/SS-2003, Límites máximos permisibles de hidrocarburos en suelos y las especificaciones para su caracterización y remediación. Secretaria de Medio Ambiente y Recursos Naturales. Diario Oficial de la Federación, México, D.F.

Stober, V. M., (1962). Vetraglichkeitsprufungen Mit Rohund Heizol an Rindern. Deutsche Tierarzliche Wochenschrift, 69, 386-390 (5 pages).

Tobias, B.; Mendoza, G. D.; Arjona, E.; García-Bojalil, C.; Suárez, M. E., (1997). A simulation model of performance 
of growing steers grazing in tropical pastures. J. Anim. Sci., 75 (Suppl. 1), 271

Wang, Y.; Ding, X., (2000). Hydrocarbon alteration characteristics of soils and mechanism for detection by remote sensing in east Sichuan area, China. Nat. Resour. Res., 9 (4), 295-305 (11 pages).

Zach, R.; Mayoh, K. R., (1984). Soil ingestion by cattle: A neglected pathway. Health Phys., 46 (2), 426-430 (5 pages).
Zavala, C., J.; Gavi, R. F.; Adams, S. R. H.; Ferrera-Cerrato, R.; Palma-López, J. D.; Vaquera, H. H.; Domínguez, E. M., (2005). Derrames de petróleo en suelos y adaptación de pastos tropicales en el Activo Cinco Presidentes, Tabasco. Terra Latinoamerica, 23 (2), 293-302 (10 pages).

\section{AUTHOR (S) BIOSKETCHES}

Adams, R. H., Research professor, Juarez Autonomous University of Tabasco (Universidad Juárez Autónoma de Tabasco - UJAT) in the southern Gulf of Mexico region, Tabsco, Mexico. His research interests include establishing risk-based remediation and restoration goal and developing novel site remediation methods, especially for rural environments in tropical and subtropical regions within developing economies. Email: drrandocan@hotmail.com

Olán-Castro, D., Director of Biosfera Tecnología Integral S.A. de C.V., a Tabasco based company providing environmental services oriented to site characterization and remediation of hydrocarbon contaminated sites in the petroleum producing region of southeastern Mexico, Tabsco, Mexico. Email: olan_donato@hotmail.com

Guzmán-Osorio, F. J., M.Sc. Student in Environmental Sciences, Juarez Autonomous University of Tabasco (UJAT). His research interests include chemico-biological stabilization, chemical stabilization/solidification, cation exchange, phytoremediation and soil restoration issues. Email: franjaguoso@hotmail.com

Díaz-Ramirez, I. J., Research professor, Juarez Autonomous University of Tabasco, Tabsco, Mexico. His research interests include site characterization, as well as isolation and improvement of hydrocarbon utilizing microorganisms for the bioremediation of hydrocarbon contaminated sites. Email: idr73@hotmail.com

How to cite this article: (Harvard style)

Adams, R. H.; Olán-Castro, D.; Guzmán-Osorio, F. J.; Díaz-Ramirez, I. J., (2009). Relationship between geomorphology and contamination with weathered hydrocarbons in an old river levee/marsh association. Int. J. Environ. Sci. Tech., 6 (4), 527-538. 